\title{
DAURAH FIKIH SALAT DI PONDOK PESANTREN IBNU QAYYIM BONE SEBAGAI UPAYA MELAHIRKAN GENERASI UNGGUL
}

\section{DAURAH OF FIQH PRAYER AT IBNU QAYYIM ISLAMIC BOARDING SCHOOL BONE AS EFFORT TO CREATE EXCELLENT GENERATIONS}

\author{
Sirajuddin \\ Sekolah Tinggi Ilmu Islam dan Bahasa Arab (STIBA) Makassar \\ sirajuddin.syarif@stiba.ac.id

\section{Saifullah bin Anshor} \\ Sekolah Tinggi Ilmu Islam dan Bahasa Arab (STIBA) Makassar \\ saifullah@stiba.ac.id

\section{Muhammad Nirwan Idris} \\ Sekolah Tinggi Ilmu Islam dan Bahasa Arab (STIBA) Makassar \\ muhammadnirwan@stiba.ac.id
}

\begin{tabular}{|c|c|}
\hline Keywords : & ABSTRACT \\
\hline $\begin{array}{l}\text { Community Service, Daurah } \\
\text { Salat, Islamic Boarding School }\end{array}$ & $\begin{array}{l}\text { Ibnu Qayyim Islamic Boarding school is a formal educational } \\
\text { institution, located in Walannae Village, Tanete Riattang Subdistrict, } \\
\text { Bone Regency.This boarding school has two levels of education, } \\
\text { namely Integrated Islamic Junior High School (SMP IT) Technology } \\
\text { and Vocational High School (SMK) with the department of Network } \\
\text { Computer Engineering. The purpose of KKN STIBA Makassar class } \\
\text { IV is to carry out community service which is one of the tri dharma } \\
\text { pillars of higher education. The method of community service } \\
\text { implementation in the cottage begins with mapping the problems and } \\
\text { needs of students by using instruments made independently combined } \\
\text { with SOAR analysis. After conducting a needs analysis, the next } \\
\text { stage is the preparation of an adaptive work program with cottage } \\
\text { conditions. Among the work programs implemented by students of } \\
\text { KKN STIBA Makassar class IV is Daurah Fikih Salat. The result of } \\
\text { the implementation of this KKN is the improvement of the } \\
\text { understanding of students around taharah and prayer that is seen in } \\
\text { the ordinances of wudoo' and prayer movements that are getting } \\
\text { better and right. }\end{array}$ \\
\hline \multirow{2}{*}{$\begin{array}{l}\text { Kata kunci : } \\
\text { Pengabdian Masyarakat, } \\
\text { Daurah Salat, Pondok } \\
\text { Pesantren }\end{array}$} & ABSTRAK \\
\hline & $\begin{array}{l}\text { Pondok pesantren Ibnu Qayyim adalah sebuah lembaga pendidikan } \\
\text { formal, terletak di Desa Walannae, Kecamatan Tanete Riattang, } \\
\text { Kabupaten Bone, Pondok ini memiliki dua jenjang pendidikan yaitu } \\
\text { Sekolah Menengah Pertama Islam Terpadu (SMP IT) Teknologi dan } \\
\text { Sekolah Menengah Kejuruan (SMK) dengan jurusan Teknik } \\
\text { Komputer Jaringan. Tujuan dari Kuliah Kerja Nyata (KKN) STIBA } \\
\text { Makassar angkatan IV ini adalah sebagai wujud pengabdian kepada }\end{array}$ \\
\hline
\end{tabular}


Website: https://journal.stiba.ac.id ISSN: 2723-6013 (Online)

\begin{abstract}
masyarakat yang merupakan pilar dari tri dharma perguruan tinggi. Metode pelaksanaan pengabdian di pondok diawali dengan memetakan masalah dan kebutuhan santri dengan menggunakan instrumen yang dibuat secara mandiri berpadu analisis SOAR. Setelah analisis dilakukan, maka disusun program kerja yang adaptif dengan kondisi pondok. Di antara program kerja yang dilaksanakan oleh mahasiswa KKN STIBA Makassar angkatan IV adalah Daurah Fikih Salat. Hasil dari pelaksanaan KKN ini adalah peningkatan pemahaman santri seputar taharah dan salat serta terlihat pada tata cara wudhu dan gerakan salat yang semakin baik dan benar.
\end{abstract}

Diterima: 25 April 2021; Direvisi: 10 Mei 2021; Disetujui: 22 Mei 2021; Tersedia online: 18 Juni 2021

How to cite: Sirajuddin, Saifullah bin Anshor, Muhammad Nirwan Idris "Daurah Fikih Salat di Pondok Pesantren Ibnu Qayyim Bone sebagai Upaya Melahirkan Generasi Unggul”, WAHATUL MUJTAMA': Jurnal Pengabdian Masyarakat Vol.2, No.1 (Juni 18, 2021): 31-39. doi: https://doi.org/10.36701/wahatul.v2i1.342

\title{
PENDAHULUAN
}

Pondok Pesantren Ibnu Qayyim adalah sebuah lembaga pendidikan formal di bawah naungan Yayasan Ibnu Qayyim Wahdah Islamiyah Bone. Pondok pesantren Ibnu Qayyim terletak di jalan Urip Sumoharjo km. 1, Desa Walannae, Kecamatan Tanete Riattang, Kabupaten Bone, Provinsi Sulawesi Selatan, Pondok ini terdiri dari dua jenjang pendidikan yaitu Sekolah Menengah Pertama Islam Terpadu (SMP IT) Teknologi dan Sekolah Menengah Kejuruan (SMK) dengan jurusan Teknik Komputer Jaringan. Jumlah keseluruhan santri SMP IT berjumlah 65 santri dan SMK berjumlah 34 santri sehingga total keseluruhan jumlah santri yang berada di Pondok Pesantren Ibnu Qoyyim sebanyak 99 santri ${ }^{1}$.

Keunggulan pondok pesantren ini terletak pada perpaduan antara kurikulum Departemen Pendidikan Nasional (Diknas) dan kurikulum pesantren serta ditunjang oleh sarana dan prasarana yang memadai ${ }^{2}$, sehingga dapat menghasilkan alumni yang memiliki life skills, akhlak mulia dan pemahaman ilmu Islam yang baik. Dengan target capaian ini diharapkan para santri yang akan menjadi lulusan pondok pesantren Ibnu Qayyim dapat pemberikan nilai tambah di tengah masyarakat.

Lulusan pondok sangat diharapkan menjadi generasi unggul dalam mengaplikasikan ilmu yang telah didapatkan, terutama ilmu syariat, sehingga hal yang berkaitan dengan masalah urgen dalam Islam selayaknya diketahui secara mendalam, misalnya salat yang merupakan ibadah terpenting setelah mengikrarkan syahadat. Kaum muslimin pada umumnya telah mengetahui gerakan salat, dan

\footnotetext{
${ }^{1}$ Profil Pondok Pesantren Ibnu Qoyyim
}

${ }^{2}$ Yayasan Ibnu Qayyim Wahdah Islamiyah Bone Menerima Siswa Baru | Wahdah Islamiyah, accessed May 19, 2021, https://wahdah.or.id/yayasan-ibnu-qayyim-wahdah-islamiyah-bonemenerima-siswa-baru/. 
menghafal bacaan salat, tetapi sedikit yang mengetahui tentang syarat sah, syarat wajib, dan rukun salat serta hal-hal yang merupakan sunah salat. Meskipun semua pembahasan tadi telah dikemas dalam kurikulum pesantren, tetapi perlu disegarkan kembali dalam bentuk daurah atau pelatihan, agar informasi yang sebelumnya didapatkan secara bertahap dalam beberapa waktu, bisa di-review dan dirangkai kembali menjadi sebuah pemahaman yang utuh.

Berdasarkan uraian profil Pondok Pesantren Ibnu Qayyim di atas, maka pelaksanaan program kerja KKN STIBA Makassar angkatan IV dinilai dapat memberikan kontribusi bagi pengembangan kualitas santri. Untuk itu, ditetapkan tujuan pelaksanaan KKN sebagai berikut:

1. Untuk mengambil peran dalam mencerdaskan anak bangsa berdasarkan nilainilai agama demi mewujudkan tujuan pedidikan nasional sebagaimana amanat Undang-undang No. 20 Tahun 2003 Bab 1 Pasal 1 Ayat $2^{3}$.

2. Untuk meningkatkan kesadaran sosial dan dakwah mahasiswa STIBA Makassar dalam berkontribusi pada peningkatan SDM masyarakat khususnya pada santri Pondok Pesantren Ibnu Qayyim.

3. STIBA Makassar sebagai perguruan tinggi keagamaan Islam berkewajiban dalam melaksanakan tri dharma perguruan tinggi pada pilar pengabdian masyarakat.

Sebelum menetapkan program kerja KKN di Pondok Pesantren Ibnu Qayyim, terlebih dahulu dilakukan survei lapangan untuk keperluan analisis kebutuhan program pemberdayaan santri, dengan mengaplikasikan instrumen sederhana dalam memetakan kebutuhan, maka kemudian dilakukan analisis SOAR secara ringkas sebagai berikut:

1. Strength, semua santri tinggal di asrama sehingga sangat kondusif untuk mengikuti kegiatan tambahan, sarana dan prasarana yang memadai untuk melaksanakan kajian-kajian fikih praktis, mahasiswa KKN dapat membantu kegiatan belajar mengajar di pondok pesantren Ibnu Qayyim, mahasiswa KKN memiliki kemampuan di bidang Teknologi Informasi (TI), Mahasiswa KKN dapat mengajar bahasa Arab, mahasiswa KKN dapat mengadakan daurah seputar fikih ibadah.

2. Opportunities, adanya dukungan dari pimpinan dan pembina pesantren, animo santri yang tinggi untuk meningkatkan kualitas keilmuan, antusias santri untuk turut menyukseskan program KKN STIBA Makassar.

3. Aspiration, kebutuhan santri akan nuansa berbeda dalam proses belajar, sebagian santri belum dapat mengidentifikasi hal yang merupakan syarat wajib salat, syarat sah salat, rukun salat, wajib salat, sunat salat dan konsekuensinya

\footnotetext{
${ }^{3}$ Undang-Undang Republik Indonesia, vol. 2003, 2021.
} 
bila terluput dalam salat, sebagian besar santri belum bisa menyelenggarakan pengurusan jenazah.

4. Result, memberikan nuansa berbeda pada KBM di pesantren, santri dapat meningkatkan kualitas diri melalui kegiatan-kegiatan yang dilaksanakan oleh mahasiswa KKN STIBA Makassar, santri dapat merealisasikan ilmu syariat yang didapatkan dalam bentuk perilaku sehari-hari.

Berdasarkan hasil analisis SOAR di atas, maka ditetapkan program kerja KKN STIBA Makassar angkatan IV di Pesantren Ibnu Qayyim yaitu: 1) Membantu proses KBM di pesantren; dan 2) Melaksanakan daurah fikih praktis seputar salat (taharah, salat dan penyelenggaraan jenazah). Dengan harapan bahwa kegiatankegitan ini dapat memberikan kontribusi dalam peningkatan SDM di tengah masyarakat kelak.

Pengabdian kepada Masyarakat (PkM) dalam bentuk KKN di pondok pesantren telah banyak dilakukan sebelumnya di beberapa tempat, di antaranya:

1. PkM yang dilakukan oleh mahasiswi KKN Universitas Islam Majapahit di Pondok Pesantren Al-Istiqomah II, Desa Bendunganjati Mojokerto. Tujuan pengabdian KKN di pesantren ini adalah meningkatkan kreativitas santri melalui karya seni Islam, yaitu pelatihan kaligrafi. Metode yang dilakukan dalam pelatihan karya seni Islam kaligrafi adalah dengan mengobservasi minat dan bakat yang dimiliki mitra melalui wawancara, melakukan metode pelatihan secara berkala selama kegiatan KKN dilaksanakan, dan metode pemasaran melalui toko online dan toko offline. Pelatihan kaligrafi ini dapat meningkatkan kreativitas dan produktivitas santri ${ }^{4}$.

2. PkM yang dilakukan oleh mahasiswa KKN Universitas Bhayangkara Surabaya di Pondok Pesantren Putri Hikmatun Najiyah Kecamatan Wonocolo. Bentuk pengabdian yang dilakukan berupa pemasangan CCTV dan akses internet, di mana hal ini bertujuan untuk meningkatkan proses belajar mengajar para santriwati maupun pengurus dan mengawasi aktivitas santriwati demi kedisplinan pondok pesantren. Dengan selesainya kegiatan program kerja para santriwati bisa lebih mudah mengakses internet di semua area pondok pesantren untuk meningkatkan pengetahuan para santriwati tentang teknologi dan informasi ${ }^{5}$.

4 Frida Setia Risfania, Khavida Rizza Umami, and Hajar Nurma Wachidah, "Upaya Peningkatan Kreativitas Dan Produktivitas Santri Pondok Pesantren Al - Istiqomah II Melalui Pelatihan Karya Seni Islam," Jurnal SNP2M (Seminar Nasional Penelitian Dan Pengabdian Masyarakat) UNIM 2 (2020): 191-196.

${ }^{5}$ Dhanu Budi Pangestu et al., "Pengembangan Pondok Pesantren Putri Hikmatun Najiyah Melalui Implementasi Internet of Things Menuju Era 5.0," Abdi Bhayangkara: Jurnal Pengabdian UBHARA Surabaya 2, no. 1 (2020): 243-249. 
3. PkM yang dilakukan oleh Khoiru Rozi di Pondok Pesantren Mamba'us Sholihin Gresik, di mana tujuan pengabdian adalah untuk mengukur peran program pengabdian bagi santri dalam meningkatkan perilaku sosial keagamaan. Dalam pelaksanaannya program pengabdian ini memberikan dampak positif dalam meningkatkan sisi religius santri dan perilaku sosialnya di tengah masyarakat ${ }^{6}$.

Berdasarkan beberapa hasil PkM yang telah disebutkan di atas tampak bahwa program pengabdian KKN mahasiswa yang dilaksanakan di pondok pesantren ini lebih mengarah kepada upaya peningkatan skills, produktivitas dan kreativitas santri. Adapun yang menjadi kekhasan dari pengabdian masyarakat yang dilakukan oleh mahasiswa STIBA Makassar terletak pada peningkatan wawasan dasar keislaman serta pembinaan akhlak masyarakat.

\section{PEMBAHASAN}

Setelah melakukan observasi lapangan untuk beberapa hari di Pondok Pesantren Ibnu Qayyim tentang bagaimana keadaan dan aktivitas kehidupan seharihari santri selama di pondok, ditemukan bahwa masih diperlukan pemantapan dan/atau pengayaan tentang sifat salat Nabi saw., serta perbaikan kesalahankesalahan dalam salat. Tujuan pelaksanaan kegiatan tidak lain untuk menanamkan pemahaman yang benar tentang tata cara salat berdasarkan tuntunan Nabi Muhammad saw., menghindari batalnya salat tanpa disadari, menambah kekhusyuan dalam salat dengan memahami makna bacaan salat serta dapat menjadi model di tengah masyarakat ketika para santri kembali ke lingkungan masing masing. Sehubungan dengannya, Iskandar dan Muhammad juga pernah melaksanakan kegiatan Daurah Qur'aniyah yang bertujuan untuk meningkatakan kemampuan dan pemahaman membaca Al-Qur'an secara baik dan benar ${ }^{7}$. Dengan demikian, berkaitan pada pemaksimalan pelaksanaan kegiatan tersebut, maka perlu persiapan dan gambaran keadaan santri terlebih dahulu, serta merencanakan kegiatan Daurah Fikih Salat .

Beberapa persiapan yang dilakukan meliputi langkah-langkah kegiatan, berupa pemetaan materi daurah fikih salat, menyusun matriks kegiatan, membentuk panitia pelaksana, mempersiapkan sarana dan prasarana acara. Kemudian materi disampaikan kepada peserta dengan menjelaskan secara langsung disertai dengan peraga di beberapa sesi tertentu dan juga dibantu dengan adanya

\footnotetext{
${ }^{6}$ Much. Khoir Rozi, "Peran Program Pengabdian Dalam Meningkatkan Perilaku Sosial Keagamaan Santri Di Pondok Pesantren Mamba'us Sholihin Gresik," Digital Library Universitas Islam Negeri Sunan Ampel Surabaya 2020, http://digilib.uinsby.ac.id/id/eprint/44539.

${ }^{7}$ Iskandar, Iskandar, and Muhammad Amirullah. "Pelaksanaan Dirasah Qur'aniyah sebagai Upaya Peningkatan Kualitas Baca Al-Qur'an di Desa Tukamasea Kabupaten Maros." WAHATUL MUJTAMA': Jurnal Pengabdian Masyarakat 1.1 (2020): 42-53.
} 
layar proyektor untuk menampilkan materi. Setelah itu, peserta diwajibkan untuk menulis materi yang disampaikan sebagai bahan evaluasi di akhir kegiatan. Adapun matriks kegiatan disajikan sebagai berikut:

\begin{tabular}{|c|c|c|c|}
\hline Hari/Tanggal & Waktu & Materi & Pemateri \\
\hline \multirow{7}{*}{$\begin{array}{c}\text { Sabtu, } 13 \text { Maret } \\
2021\end{array}$} & $16.10-17.15$ & Keutamaan salat & Dandi \\
\hline & & Kewajiban salat 5 waktu & Dandi \\
\hline & & Waktu-waktu salat & Dandi \\
\hline & $20.10-21.45$ & Syarat-syarat salat & Dandi \\
\hline & & Ruku-rukun salat & Dandi \\
\hline & & Wajib-wajib salat & Dandi \\
\hline & & Sunah-sunah salat & Dandi \\
\hline \multirow{4}{*}{$\begin{array}{c}\text { Ahad, 14 Maret } \\
2021\end{array}$} & $08.00-09.10$ & Pembatal-pembatal salat & Dandi \\
\hline & & $\begin{array}{l}\text { Hal-hal yang dimakruhkan } \\
\text { dalam salat }\end{array}$ & Dandi \\
\hline & & Pembatal-pembatal salat & Dandi \\
\hline & $13.00-14.30$ & $\begin{array}{l}\text { Kesalahan-kesalahan } \\
\text { dalam salat }\end{array}$ & Ibnu Hajar \\
\hline
\end{tabular}

Pengalaman menarik yang didapatkan selama kegiatan tersebut tampak tatkala para santri terlihat sangat antusias untuk ikut serta dalam kegiatan, sehingga penguasaan terhadap materi sebelum acara berlangsung sangat dibutuhkan oleh pemateri. Selain itu, dari kegiatan ini, bagi pemateri, penting untuk mengetahui keadaan santri dalam memahami materi untuk kemudian menjadi bahan evaluasi kegiatan. Sehubungan dengannya pula, perencanaan yang baik dan matang dalam setiap kegiatan guna mengukur hasil yang dicapai adalah sesuatu yang sangat penting.

Dari kegiatan ini pula, faktor yang mendukung terselenggaranya acara ialah ketersediaan sarana dan prasarana yang memadai sehingga menunjang kesuksesan kegiatan. Tidak hanya itu, kontribusi pembina pondok pesantren dalam membantu fungsi pengontrolan santri sebelum, sesaat dan sesudah daurah. Akan tetapi, dalam kegiatan ini ditemukan juga kendala yang cukup berarti, di mana pengalaman pertama mahasiwa KKN STIBA dalam menyampaikan materi menjadi salah satu hambatan, yakni kurangnya penguasaan keadaan audience (pendengar/jemaah) dan teknik penyampaian materi secara visual dan audio visual. Dengan demikian, sebagai langkah solutifnya ialah dengan membagi kelompok peserta berdasarkan metode pendekatan yang disesuaikan berupa kelompok visual, audio visual dan kinestetik. 

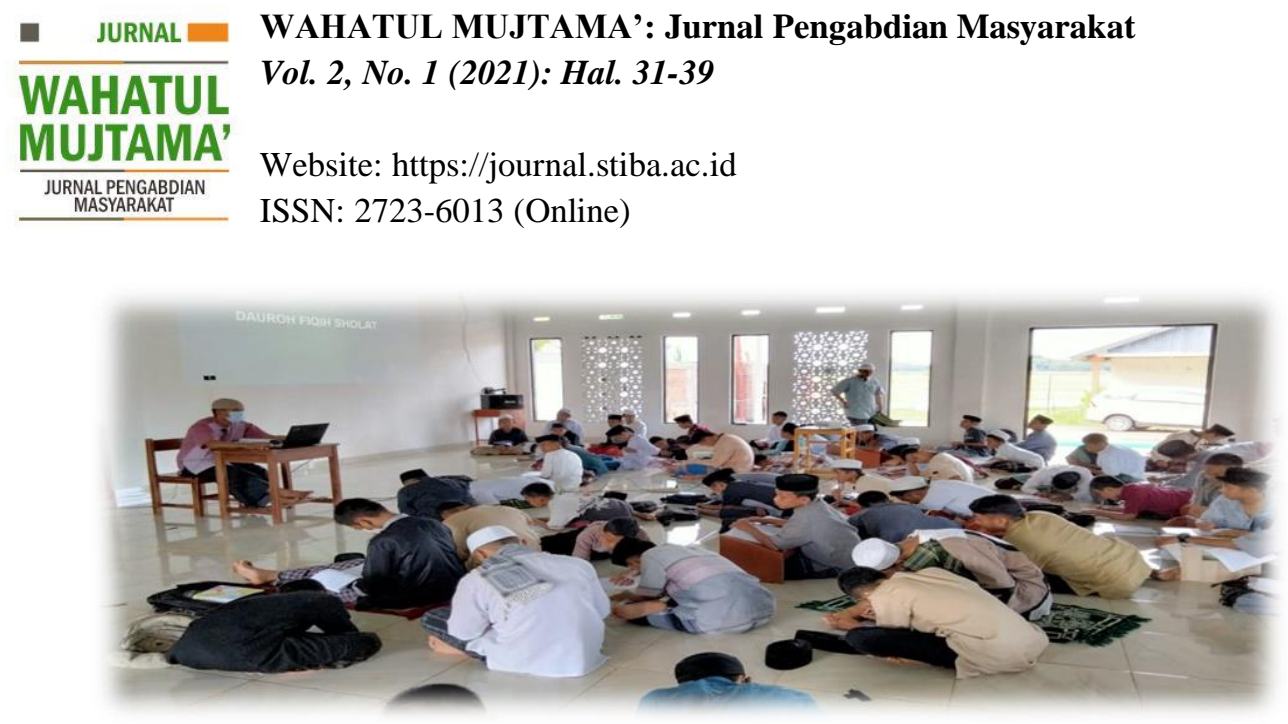

Gambar 1. Penyampaian Materi pada Daurah Fikih Salat

Berdasarkan hasil kegiatan Daurah Fikih Salat ini, ditemukan gambaran kondisi santri sebelum mengikuti kegiatan daurah fikih salat, yaitu:

1. Minimnya pengetahuan santri terutama bagi santri baru tentang tata cara salat yang sesuai dengan sunah Rasulullah saw.

2. Para santri masih belum menguasai perbedaan antara rukun dan wajib salat.

3. Para santri masih sering ditemukan dalam praktik kesehariannya menampilkan kesalahan dalam salat.

4. Bagi santri baru, mereka belum memahami beberapa dalil berkenaan gerakan sunah salat, dan hanya sekedar mengikuti gerakan jemaah lain yang dilihatnya.

Adapun setelah kegiatan berlangsung, ditemukan kebanyakan santri memperlihatkan kondisi sebagai berikut:

1. Santri dapat memahami begitu pentingnya perkara salat dalam agama yang merupakan hal terpenting setelah kalimat tauhid.

2. Adanya peningkatan pemahaman santri mengenai tata cara salat yang benar, walaupun masih perlu ditingkatkan kembali.

3. Santri secara umum telah memahami pelaksanaan salat, mulai takbiratul ihram sampai salam, meskipun masih dalam tahap pengenalan atau hal-hal dasar.

4. Adanya peningkatan kemantapan dalam setiap gerakan salat seperti rukuk dan sujud yang benar.

5. Santri dapat membedakan antara rukun-rukun dan wajib-wajib salat.

6. Ada perubahan bagi santri sebelum dan sesudah mengikuti daurah dengan pengaplikasiannya materi yang didapatkan.

7. Berdasarkan evaluasi, 40 dari peserta santri menyatakan bahwa ada perubahan dalam salat mereka setelah mengikuti Daurah Fikih Salat. 


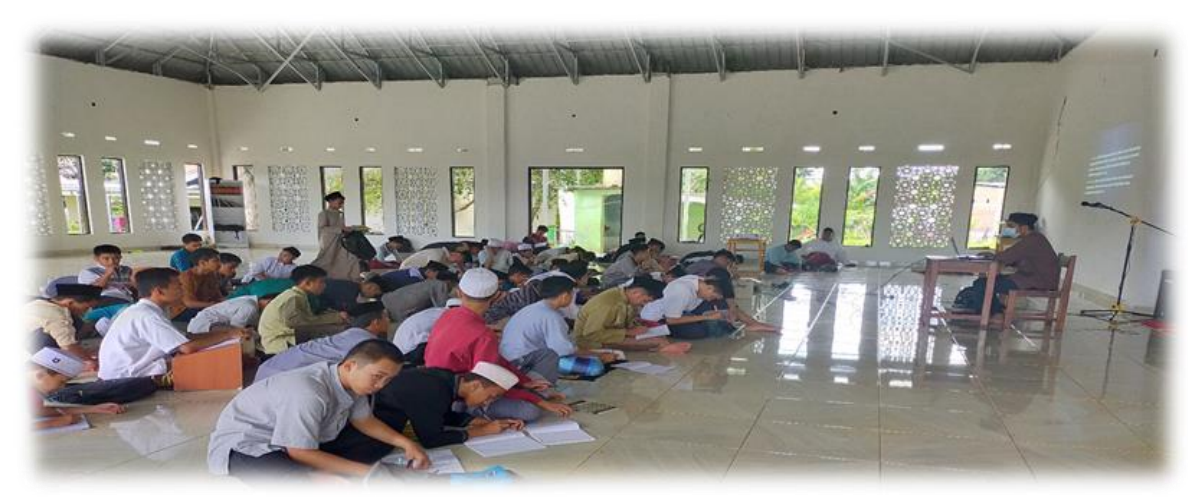

Gambar 2. Evaluasi Pembelajaran pada Daurah Fikih Salat

Setelah pelaksanaan kegiatan Daurah Fikih Salat ini dan mengevaluasi hasilnya, maka hasil yang telah dicapai tersebut adalah dapat dijadikan sebagai titik awal oleh pengasuh pondok pesantren atau mahasiswa KKN berikutnya untuk kemudian dapat melakukan pendampingan pada hal-hal yang masih perlu dibenahi dan melanjutkan pembinaan pada masalah fikih yang lainnya. Sejatinya, menurut Sri dan Aswar mengutarakan bahwa upaya follow up pada kegiatan PkM yang bersifat sustainable (berkelanjutan) itu penting guna pengembangan kualitas SDM masyarakat dan/atau melahirkan generasi unggul di tempat pelaksana $\mathrm{PkM}$ mengabdi ${ }^{8}$.

\section{KESIMPULAN}

Kuliah Kerja Nyata (KKN) STIBA Makassar angkatan IV ini adalah sebagai wujud pengabdian kepada masyarakat yang merupakan pilar dari tri dharma perguruan tinggi. Di antara program kerja yang dilaksanakan oleh mahasiswa KKN STIBA Makassar angkatan IV di Pondok Pesantren Ibnu Qayyim adalah Daurah Fikih Praktis seputar taharah dan salat. Hasil dari pelaksanaan KKN ini adalah terjadinya peningkatan pemahaman santri seputar taharah dan salat serta terlihat perubahan pada cara wudhu dan gerakan salat yang semakin baik dan benar pada diri santri.

\section{DAFTAR PUSTAKA}

Iskandar, Iskandar, and Muhammad Amirullah. "Pelaksanaan Dirasah Qur'aniyah sebagai Upaya Peningkatan Kualitas Baca Al-Qur'an di Desa Tukamasea Kabupaten Maros." WAHATUL MUJTAMA': Jurnal Pengabdian Masyarakat 1.1 (2020): 42-53.

Pangestu, Dhanu Budi, M. Faisal Aditya, Ula Aulia, and M. Mahaputra Hidayat.

${ }^{8}$ Putri, Sri Ujiana, and Aswar Aswar. "Implementasi Pendidikan Masyarakat Berbasis Masjid untuk Muslimah di Desa Mattoanging Kabupaten Maros." WAHATUL MUJTAMA': Jurnal Pengabdian Masyarakat 1.2 (2020): 129-141. 
- Jurnal $\quad$ WAHATUL MUJTAMA': Jurnal Pengabdian Masyarakat

WAHATUL Vol. 2, No. 1 (2021): Hal. 31-39

"Pengembangan Pondok Pesantren Putri Hikmatun Najiyah Melalui Implementasi Internet of Things Menuju Era 5.0." Abdi Bhayangkara: Jurnal Pengabdian UBHARA Surabaya 2, no. 1 (2020): 243-249.

Putri, Sri Ujiana, and Aswar Aswar. "Implementasi Pendidikan Masyarakat Berbasis Masjid untuk Muslimah di Desa Mattoanging Kabupaten Maros." WAHATUL MUJTAMA': Jurnal Pengabdian Masyarakat 1.2 (2020): 129141.

Risfania, Frida Setia, Khavida Rizza Umami, and Hajar Nurma Wachidah. "Upaya Peningkatan Kreativitas Dan Produktivitas Santri Pondok Pesantren Al Istiqomah II Melalui Pelatihan Karya Seni Islam." Jurnal SNP2M (Seminar Nasional Penelitian Dan Pengabdian Masyarakat) UNIM 2 (2020): 191-196. Rozi, Much. Khoir. "Peran Program Pengabdian Dalam Meningkatkan Perilaku Sosial Keagamaan Santri Di Pondok Pesantren Mamba'us Sholihin Gresik." Digital Library Universitas Islam Negeri Sunan Ampel Surabaya, 2020. http://digilib.uinsby.ac.id/id/eprint/44539.

Undang-Undang Republik Indonesia. Vol. 2003, 2021.

"Yayasan Ibnu Qayyim Wahdah Islamiyah Bone Menerima Siswa Baru | Wahdah Islamiyah." Accessed May 19, 2021. https://wahdah.or.id/yayasan-ibnuqayyim-wahdah-islamiyah-bone-menerima-siswa-baru/. 